\title{
EMMANUEL LÉVINAS: DOMOV A UMĚNÍ
}

\author{
DANIELA MATYSOVÁ \\ Fakulta humanitních studií Univerzity Karlovy \\ andrda@seznam.cz
}

\begin{abstract}
Emmanuel Lévinas: Home and Art

In this paper, we focus on the explanation of the essence of artistic experience elaborated by Emmanuel Lévinas based on his philosophical conception of „home“. Lévinas says that the true meaning of art lies in the possibility to make us realize the true sense of „being home" does not refer to our selfish need of inhabitancy at all but to our ethic relations with other people.
\end{abstract}

Keywords: Art - philosophy - etics - home - Emmanuel Lévinas

Domov a umění: umění, které by nám přinášelo pocit, že někam patříme, útěchu a naději navzdory těžkostem a strastem - anebo umění, které nás nechává spočívat v klidu, zajištěnosti a bezpečí, jinak řečeno, díky němuž se cítíme doma u sebe sama? Tento rozdíl mezi dvěma alternativními návrhy na výklad toho, co dělá umění vlastně uměním čili čím na nás ve své zvláštnosti a výjimečnosti působí, se nemusí zdát na první pohled nikterak srozumitelným, protože není jasné, proč by mělo jít právě o dvě protichůdné možnosti. A proč by to nemohlo být tak, že nám umění otevírá jistou možnost, jak se cítit doma v ne vždy přivětivém světě, která by zároveň znamenala i to, že se cítíme zabydlení tehdy, vychází-li svět vstříc našim potřebám, věci se nám poddávají a jsou tu právě pro nás?

Na tuto otázku se v následujícím textu pokusíme odpovědět pomocí textů významného francouzského filosofa 20. století Emmanuela Lévinase. Poněvadž je to právě on, kdo jednak ve svých textech propojil otázku po tom, co je podstatou umění, s náhledem, že důležitou roli tu sehrává právě jeho schopnost pomoci nám v každodenních složitostech života ve světě najít pocit, že přese všechno jsme v něm doma - a zároveň trvat na tom, abychom se naučili důsledně rozlišovat, co toto „zabydlování může v různých př́padech znamenat. Jinými slovy se nás Lévinas táže: chceme po umění, aby nám přinášelo sílu naděje a víry do veškerého nutného úsilí v péči o svět, který tímto staráním se činíme svým domovem - anebo naopak toužíme po tom, aby nám umění pomáhalo před starostmi a strastmi vyplývajícími z tohoto nekončícího úsilí unikat tím, že nám dovoluje uzavřít se ryze do sebe sama, do naší osobní skrýše, kde hledáme sebezajištění? Toto jsou podle Lévinase dvě různé a přímo protikladné zkušenosti, jimž nás různá umělecká díla mohou vystavovat. A to nikoli tím, že by snad musela motiv domova tematizovat, ale tím, že nás ve svém zvláštním působení přivádí přímo $\mathrm{k}$ prožitku toho, co pro nás znamená cítit se na světě doma. 
Abychom si mohli blíže vysvětlit, jak tedy máme podle této Lévinasovy perspektivy rozumět tomu, co je vlastní podstatou umělecké působivosti, je potřeba nejdříve zdůraznit a mít na paměti dvojí. Za prvé, jak jsme již řekli, Lévinasovy filosofické poznámky implikují, že umění na nás působí dvěma velmi odlišnými způsoby, což znamená, že i samotné vymezení podstaty estetické působivosti nabývá rozdílného smyslu. A za druhé je tomu navíc tak, že Lévinas jen jeden $\mathrm{z}$ těchto způsobů považuje za žádoucí, zatímco ten druhý př́mo za zavrženíhodný. Abychom tedy pochopili, jakých dvou rozdílných úloh může umění v našem životě nabývat, začneme od podrobnějšího vysvětlení druhého jmenovaného případu. Tedy toho, kdy nás umělecká díla svádějí svou nabídkou ulevit si, jenže podle Lévinase to dělají vždy „sobecky a zbaběle“1, uzavřením se před obtížemi života $\mathrm{v}$ sobě samém, zabydlením se ve vlastním bytí.

Než ale můžeme vyložit, proč tuto schopnost umění Lévinas považuje za odsouzeníhodnou, vysvětleme si, co se oním unikáním do bezpečí vlastního bytí skrze umění vlastně míní. Nejprve zcela obecně: Lévinas navazuje na dlouhou myslitelskou tradici a ptá se, proč oceňujeme umělecká díla a co je činí tak speciálními mezi dalšími př́írodními věcmi či lidskými výtvory, událostmi, úkazy a tak podobně? Nejsou umělecká díla výjimečná právě tím, že na nás právě nepůsobí jako všechny ostatní „běžné“ objekty našeho všedního zacházení, vnímání, cítění, poznání či myšlení? Že nám právě neslouží jako prostředky $\mathrm{k}$ cílům a účelům, at už spirituálním, nebo třeba matematickým, $\mathrm{k}$ obživě, práci nebo našemu pocitu pohodlí? Ale nevyjímají se též z kategorie věcí, které jsou nám naopak „k ničemu“ a o které se vůbec nezajímáme a jsme k nim lhostejní? Zdá se, že naše setkávání s uměním mají přesně opačný, ale záhadný charakter: zjevně nás poutají, zajímají a fascinují, i když skutečně takříkajíc nejsou k ničemu. Nikoli však ve smyslu, že by umělecká díla byla nefunkční, ale spíše právě proto, že nejsou k žádnému užitkovému fungování vůbec určena (ač nelze popřít, že z pohledu užitečnosti se na ně dá vždy neprávem nazírat: obraz můžeme považovat za vhodný artefakt pro zakrytí děr ve zdi). Odpovědi na to, $v$ čem pak tedy význam a hodnota umění pro člověka spočívá, byly podány $\mathrm{v}$ dějinách filosofie a estetiky nespočetnými způsoby, my se ale přidržíme Lévinasova výkladu, podle něhož pro nás přestává umělecké dílo hrát roli obyčejné věci právě tím, že nás ze světa našich běžných postojů (určujících naše jednání, cítění, myšlení apod.) $\mathrm{k}$ věcem kompletně vytrhuje. ${ }^{2}$

Je ale jistě otázka, co nám zůstává, jsme-li skutečně a v hlubokém smyslu odtrženi od toho, co děláme v každodenním životě neustále: od naší možnosti vnímat věci právě jako věci důvěrně známé, určené právě naší životní praxí čili jako jevy a události nějak prakticky identifikovatelné. Lévinas nám odpovídá, že tímto odvratem od světa určitelných entit a jevů se navracíme $k$ hlubokému prožitku našeho původního a vlastního bytí. A to samo se prostě na "toto či ono"3 , na jednu z věcí či událostí na světě mezi ostatními, redukovat nedá. Poněvadž naše vlastní bytí je přece to neuchopitelné, nedefinovatelné a neurčitelné, co vždy leží před (protože jej podmiňuje) každým výkonem myšlení, jednání, chápání a určování významu věcí, bytostí či naší vlastní identity.

Jak si ale takové bytí, které znamená naše bytí-sám-sebou a bytí pro sebe, představit? Pro Lévinase je to zcela konkrétní prožitek našeho nejpůvodnějšího sepětí se světem,

\footnotetext{
Emmanuel Lévinas, Realita a její stín, Filozofický časopis LVII, 2009, č. 6, s. 884.

Lévinas, Realita a její stín (pozn. 1), s. 875.

Emmanuel Lévinas, Autrement qu'être ou Au-delà de l'essence, Paris 2017, s. 69-71.
} 
hluboce skrytého a prekrytého vším každodenním manipulováním a organizováním světa rozřazeného na místa naplněná svým účelům odpovídajícími věcmi a na čas určený definovatelnými událostmi a věčnými úkoly. Cítit své původní bytí na světě znamená onen konkrétní prožitek plnosti, v němž se nás svět dotýká jako sama neustále proudící změna počitků, intenzit, barev, hebkostí a tónů, které však pro jednou okamžitě obratem nepřevádíme na nějaké identifikovatelné kvality a části objektư, ${ }^{4}$ ale jimiž se - a to právě díky schopnostem umění - necháváme unášet a kolébat v libém prožívání naší sounáležitosti a jednoty se světem, v níž ještě nejsme rozděleni na proti sobě stojící chápající subjekt a od něj oddělené chápané objekty. Pokud nás tedy některá umělecká díla umí přivádět k prožitku bytí, pak estetická zkušenost v tomto smyslu znamená možnost vzdát se myšlení, kategorizování, manipulování a být jen pohlcen a fascinován vlastní neuchopitelností a nevýslovností a magickou tajemností toho, jak jsme ve svých zapomenutých hlubinách dáni světu a jak svět daný nám - jak jsme v něm doopravdy zakořeněni a doma.

Proč však Lévinas (na rozdíl od většinového smýšlení různých estetických škol 20. století, které tuto působivost umění považovaly za jeho svrchovanou a nedocenitelnou hodnotu) tento druh uměleckého působení tak hrubě kritizuje, kupříkladu coby „dílo d’áblovo"?5 Je tomu tak $\mathrm{z}$ toho důvodu, že se Lévinas na celou záležitost nechtěl dívat zrovna $z$ oné perspektivy toho, jak je úchvatné, můžeme-li se opět setkávat s věcmi a jevy tak, jako by se teprve rodily a my s nimi, aniž bychom je hned redukovali na nějaké koncepty a prostředky - ale začal se zaobírat myšlenkou, co toto „neredukování“ světa na upotřebitelné věci našeho běžného užívání znamená z druhé strany. Neznamená toto př̀evládnutí prožitku čistého bytí se světem právě to, že se odvracíme od všeho rozumného uvažování a od naší bytostné odpovědnosti za starání se o svět v jeho upotřebitelnosti a obstarávatelnosti, v němž se ale přece ve svých obyčejných životech musíme snažit přežít spolu s druhými lidmi především?

Nebot' mít odpovědnost za tento reálný svět poznatelných, zhotovených nebo třeba nedobytných a nevyužitelných věcí nemusíme přece dopředu chápat jen jako pouhé honění se za ukájením svých osobních potřeb, kde vykořistujeme a terorizujeme svět v jeho původní bohatosti. Věci ve své užitečnosti, svět zkrocený ve své neuchopitelnosti nekončících řad měnících se počitků, odkazuje přece nejen na to, že máme potřebu zabezpečit a „zpohodlnit“ vlastní život. Ale především na to, že naše snaha učinit svět místem ovladatelným, ale především obyvatelným, vyjadřuje naši starost, aby v něm nalezli domov a bezpečí naši blízcí. ${ }^{6}$ A ty bychom podle Lévinase měli upřednostnit jak před zajištováním vlastního pohodlí, tak i před touhou oddávat se slastnému prožitku našeho bytí v jednotě se světem, kráse.

Obavy a oddanost druhým je pro Lévinase hlavním smyslem vší práce, dřiny, rozvoje poznávání, a nakonec i techniky, tedy našeho praktického vztahu ke světu - z něhož nám umění v prvním zpo̊sobu své působivosti, jak jsme viděli výše, ovšem pomáhá uniknout. Tím, že mě nechává prodlévat jen v proživání mého splývání s účely ještě nespoutaným světem, kde se vzdávám praktického uvažování a rozumem vedeného jednání (zohledňujícího nejen mě, ale i ostatní), tím, že mi dává možnost zapomenout na strasti našeho každodenního shonu - tím mi takové umění pouze dovoluje schovat se za hradby totální

4 Emmanuel Lévinas, Existence a ten, kdo existuje, Praha 2009, s. 44.

Lévinas, Realita a její stín (pozn. 1), s. 884.

6 Emmanuel Lévinas, Totalita a nekonečno (Esej o exterioritě), Praha 1997, s. 192. 
zaujatosti proudem bytí na úkor mého zájmu o potřeby druhých čili uniknout do bezpečí jakési sobecké hluchoty zřeknutím se uvažování o reálných záležitostech. Propadnout nezávazné libosti díky takovému umění, to znamená zapomenout na závazky: na ty, které mám vưči sobě a vůči druhým a které ode mě vždy vyžadují, abych překročil svou touhu po úlevě, po úniku, a snažil se rozumně přemýšlet, pracovat s věcmi a zvládat situace tak, abych druhým lidem mohl pomáhat v nouzi stejně, jako oni pomáhají mně, a abychom měli šanci sdílet radosti a neštěstí.

Tím se však dostáváme k problému, zdali pro Lévinase umění vždy vede k této bezohlednosti a egoismu, k této možnosti být zabydlen sám v sobě a být svobodným v hluchotě vůči prosbám druhých ${ }^{7}$ - což znamená dosti vážnou obžalobu umělecké tvorby -, anebo nenabízí-li ještě jiné vysvětlení toho, jak na nás umělecká díla mohou působit. Jak bylo řečeno $\mathrm{v}$ úvodu, přesně k takovému alternativnímu návrhu Lévinas ve svých textech dospívá, avšak prvně nás asi zajímá to, jak je možné, aby jednou umění působilo tak a po druhé onak. Je to z mé strany víceméně spekulace, ovšem domnívám se, že, jelikož Lévinas poměrně často spojoval své popisy prožívání čistého bytí s pojmy, jako je zábava či uvolnění ${ }^{8}$, mohli bychom to spíše vnímat tak, že nás tímto způsobem zasahují jen jisté formy děl, které nás prostě uchvacují svým snadno přístupným půvabem a líbivostí. Které přijímáme s jakousi lehkostí, bezprostředností a bezmyšlenkovitostí, i když se nějaké myšlenky a problémy skrývat zdají, ovšem jen za pláštíkem rychle dostupného rozřešení. Nebo kupříkladu kulturní produkty, které nás lehce zabavují a přináší momenty odpočinku v nenáročném a docela přirozeném oddání se znělce, rytmu, vzrušujícím zápletkám či sledu obrazů, co nás rychle a spolehlivě dokážou strhnout, abychom v nich na sebe a jiné zapomněli.

\section{Helene Delmaire - Eyeless girl}

Zdá se mi tudíž, že Lévinas na umělecká díla, nemají-li mít pouze tuto hodnotu „vytržení, klade požadavek, aby nám nikoli ulevovala od dřiny a těžkostí, ale aby nás ke skutečnému smyslu pro odpovědnost práce na uchování tohoto světa teprve přiváděla. Leč nikoli proto, aby nás snad vystavovala beznaději tvrdého a někdy krutého žití, ale naopak: aby nám namísto nabídky úkrytu v sobě, což není žádný skutečný, ale jen dočasný únik ${ }^{9}$, vnesla do naší práce naději a pocit, že žít a bydlet na tomto těžkém světě je přece jen úkolem smysluplným. Nicméně je třeba si uvědomit, že i když jsme řekli, že umělecká díla v prvním uvažovaném smyslu jsou „nemorálními“ právě proto, že nás odlákávají od rozumného jednání a pohlížení na svět, přes to všechno není ještě garantován opak: že snad každé lidské praktické jednání je vždy a zcela automaticky vedeno etickou ohleduplností k druhým. A že díla s etickou působností dokážeme vytvořit, ocenit či zaslechnout. Je tomu tak proto, že se etice musíme teprve učit a nikdy nemáme skončeno: vždy tak ve svém běžném, každodenním myšlení a jednání stojíme na křižovatce mezi etikou a sobectvím.

\footnotetext{
Lévinas, Totalita a nekonečno (pozn. 6), s. 74.

Viz Lévinas, Autrement qu'être (pozn. 3), s. 138.

Emmanuel Lévinas, Cvičenie zo šílenstva dňa, Filozofia LXIV, 2009, č. 3, s. 236.
} 
Zprvu totiž zcela přirozeně a nevědomky vycházíme právě z onoho de facto egoistického prazákladního „zabydleni“" ve světě, o němž byla řeč výše, které znamená, že svět se mému bytí nějak dává a já jsem jím naplněn a pro sebe v sobě zcela spokojen. Nebot ještě nevím nic o jeho nezávislosti na mě, nic o tom, že tu není jenom pro mě, a mám jej jen v naprosté blízkosti, ve splynutí, jako by tu byl a bude pouze pro mě samotného. Na druhou stranu přichází do tohoto mého zabydlení ve světě intervence, kterou do něj vnášejí druzí lidé, jakmile se s nimi setkávám. Druzí lidé mi svým vstupem na scénu odhalují, že svět tu není jen pro mé potřeby a vlastnění: druzí mi svět vytrhují jako výlučně a jedině můj.

Teprve druzí mi ukazují, že svět je společnou půdou pro všechny a že teprve v naší vzájemné komunikaci mohou vzniknout nějaká praktická měřítka porozumění věcem v jejich nezávislosti na mně (a jakémkoli jednotlivci), čili v jejich pravdě. ${ }^{10}$ Druzí na mě totiž svou bídou a utrpením kladou vždy nárok, abych jim to, co je mé, nabídl jako dar, abychom ve vzájemném soucitu a milosrdenství sdíleli věci společně, čímž mě pozvedávájí $\mathrm{k}$ dobru samotnému: od bytí pro sebe $\mathrm{k}$ bytí pro druhé a $\mathrm{k}$ bytí spolu s druhými ve vzájemné pomoci a ohledech. A pokud naše jednání, myšlení a rozhodování stojí vždy na křižovatce, znamená to pouze tolik, že je třeba převzít odpovědnost za naši vlastní svobodu: nikdy tomu není tak, že bych snad, navzdory zpochybnění mého egoismu druhými, nemohl tuto výzvu k dobru a odpovědnosti přeslechnout a pochybit - anebo se ke svému sobectví a ignoraci citů či potřeb druhých rozhodnout vědomě.

Tím, jak se naše vztahy s druhými automatizují, jak často upadáme v potřebu s druhými jednat podle sady připravených nálepek, abychom se s nimi nemuseli zaplétat, nebo jako s prostředky pro dosažení svých vlastních cílů, je o to více třeba takového umění, které by nám připomínalo to, co nás ve skutečnosti činí lidmi ${ }^{11}$ - naši lidskost a schopnost postavit bytí druhého nad zájem o svoje vlastní bytí a spokojenost, na schopnost soucítit s druhým až k hranici toho, že sám trpím, ke schopnosti nenechat druhého v jeho bolesti o samotě. Takové umění, umění, jehož nejvyšší hodnotou by bylo probouzet v nás možná někdy již opomíjený smysl lidskosti, se potom musí stát přesným opakem takových děl, která slouží k rozptýlení a uvolnění. Je to umění, které nás nemá navracet $\mathrm{k}$ tomu být sám sebou, $\mathrm{k}$ tomuto bezpečnému domovu $\mathrm{v}$ sobě sama, kam se mohu utéct před vnějšími požadavky, ale které nás v tomto smyslu má odtrhávat od sebe samých tím, že nás povolává $k$ druhým, tím, že jakoby vyjadřuje, ne pouze popisuje, jejich prosby, přání, radosti, tím, že nás nechává prožívat jejich př́iběhy, problémy a emoce, tím, že se i v těch nejabstraktnějších melodiích a liniích jakoby projevuje svět jako místo, kde žili a budou žít své životy jiní.

\section{Rembrandt Harmenszoon van Rijn - Mladá žena ve dveřích}

Toto umění nás tudíž rovněž, podobně jako tomu bylo v prvním prŕípadě egoistické estetické libosti, svým způsobem vytrhuje od zaběhnutého vnímání a škatulkování věcí, bytostí, př́rody i lidí, ale jiným způsobem. Ne tak, že nám umožní ponorem do jejich

10 Lévinas, Totalita a nekonečno (pozn. 6), s. 67-68.

11 Emmanuel Lévinas, Jean Atlan et la tension de l'art, in: Atlan: premières periodes, 1940-1954, Nantes 1986, s. 19. 
prostého, ještě neurčeného bytí opustit doménu určujícího myšlení a chápání, ale tak, že ve věcech nechává promlouvat to vše, čím se mému bytí právě nikdy nevydávají, čím mi nikdy nepatří. Umění zjevuje věci nikoli tak, jak je už dobře známe a jak o nich už automaticky smýšlíme, ale nechává je přicházet $\mathrm{v}$ tom, čím jsou pro nás vždy nové a neznámé, v tom, čím oznamují přítomnost druhého člověka: čím oznamují to, co do nich nikdy nemohu vložit já a čeho se nemohu zmocnit, co z nich činí svým životem druzí. Tím ovšem umění nedestruuje naši schopnost rozumět a uvažovat, ale odvrací naše myšlení a konání od jejich tendence $\mathrm{k}$ habituaci, k jisté lhostejnosti a k jistému zvyku dělat vše tak, jak mi to nejlépe sedí, i když to možná již dávno nějak ubližuje druhým. Umění navrací naše chápání světa k jeho inteligibilitě, schopnosti sebekritiky a rozumnosti, jimiž nejsou pouhé principy ekonomizace a efektivnosti, ale předně práva a spravedlnosti: umění nás vyučuje tomu, že věci ve své něžné i tvrdé zvláštnosti a neznámosti odhalují svůj enigmatický smysl pramenící z toho, že tu jsou pro nás pro všechny. Že přišly od těch, co byli před námi a nesou znamení všech, kteří jsou právě tady a ted’ s námi, a také apelují na to být uchovány a proměněny pro ty, co přijdou po nás.

A tak můžeme shrnout, že máme-li pocit, že ve skutečném umění na nás témbry, gesta, hrany, křivky či prŕběhy působí tak, jako kdyby v nich svět promlouval v jisté kráse a v jisté nezachytitelnosti, je tomu tak proto, že umění nechává vyvstávat svět v tom, čím není domovem a jistotou jen pro mě, ale v čem je Božím dílem: domovem nás všech. Domovem, který nám umožňuje prožít život ve vzájemnosti, blízkosti, soucitu a spravedlnosti, ačkoli to znamená neustále učit se korigovat naši potřebu si jej přivlastnit - kupř́íkladu $\mathrm{v}$ našich představách, jak by věci měly být, tedy $\mathrm{v}$ netoleranci, $\mathrm{v}$ uzavřenosti, rigidnosti a bezohlednosti, v níž prcháme od nároků sebeoběti čili štědrosti, obětavosti a schopnosti uznat a překročit naše vlastní limity. Nebot’ etika znamená i bolest a nekončící odříkání, ale přesto bolest, která má smysl, jelikož dává smysluplnost našemu životu s druhými a pro druhé, kteří nás samé nenechávají v našem utrpení o samotě, stejně jako s námi sdílejí naše radosti a štěstí.

Cílem pravého umění tedy není pomáhat nám zabydlet se ve světě tak, abychom cítili klid a pohodlí. Naopak nás dokonce právě z této zabydlenosti v sobě a u sebe samých, našich bezpečných a osvojených postojů a představ, vyhání - ale jenom proto, aby nás nutilo vzpomenout si a pocítit, že skutečný pocit domova leží v tom, že nejsem sám a opuštěný, ale že jsou tu moji blízcí, kteří nám svou péčí i potřebností vždy dodávají novou kuráž, vytrvalost a víru ve smysluplnost našich společných životních cest s jejich překážkami a nutností úsilí.

\section{SUMMARY}

\section{Emmanuel Lévinas: Home and Art}

In this paper, we focus on the explanation of the essence of artistic experience presented in texts of French philosopher Emmanuel Lévinas. We are going to elaborate on Lévinas's idea that the problem of home - what should be its proper meaning - is tightly connected with the question of what makes art so extraordinary and important for us. And we are interested mainly in the fact Lévinas offers not one but two possible and even 
contradictory answers. Either the works of art affect us so powerfully because they allow us to experience the feeling of being home within our original and non-usual bond with the world or, on the other hand, they precisely destroy these ties. Nevertheless, only in the second case, Lévinas says, thanks to the art we are able to realize that true sense of „being home" does not refer to our personal inhabitancy but to our relations with others who always teach us that the world is never exclusively ours and therefore is so enigmatic and thus so beautiful. The paper tries to explain Lévinas's ideas on home through two artworks from different periods, Helene Delmaire's Eyeless girl, 2015, and Rembrandt's Young Woman at an Open Half-Door, 1645.

\section{VÝBĚROVÁ BIBLIOGRAFIE}

Emmamanuel Lévinas, Cvičenia zo šílenstva dne, Filozofia LXIV, 2009, č. 3, s. 229-237.

Emmanuel Lévinas, De l'oblitération: entretien avec Françoise Armengaud à propos de l'œuvre de Sosno, Paris 1990.

Emmanuel Lévinas, Etika a nekonečno, Praha 2009.

Emmanuel Lévinas, Existence a ten, kdo existuje, Praha 2009.

Emmanuel Lévinas, Jean Atlan et la tension de 1'art, in: Atlan: premières periodes, 1940-1954, Nantes 1986, s. 19-20.

Emmanuel Lévinas, Noms propres, Montpellier 1982.

Emmanuel Lévinas, Realita a její stín, Filozofický časopis LVII, 2009, č. 6, s. 871-886.

Emmanuel Lévinas, Sur Maurice Blanchot, Montpellier 1995.

Emmanuel Lévinas, Totalita a nekonečno (Esej o exterioritě), Praha 1997. 


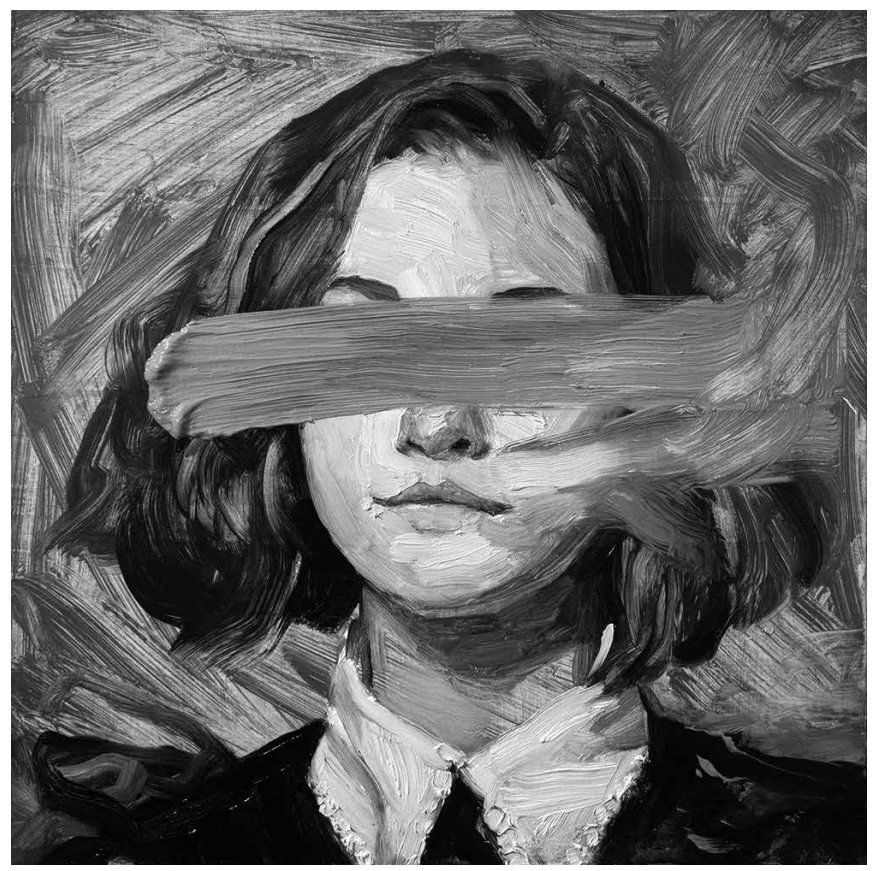

Obrázek 1. Helene Delmaire, Eyeless girl, 2015. Soukromá sbírka. https://helenedelmaire.bigcartel.com /product/eyeless-girl-limited-edition-print-1, vyhledáno 14. 1. 2021

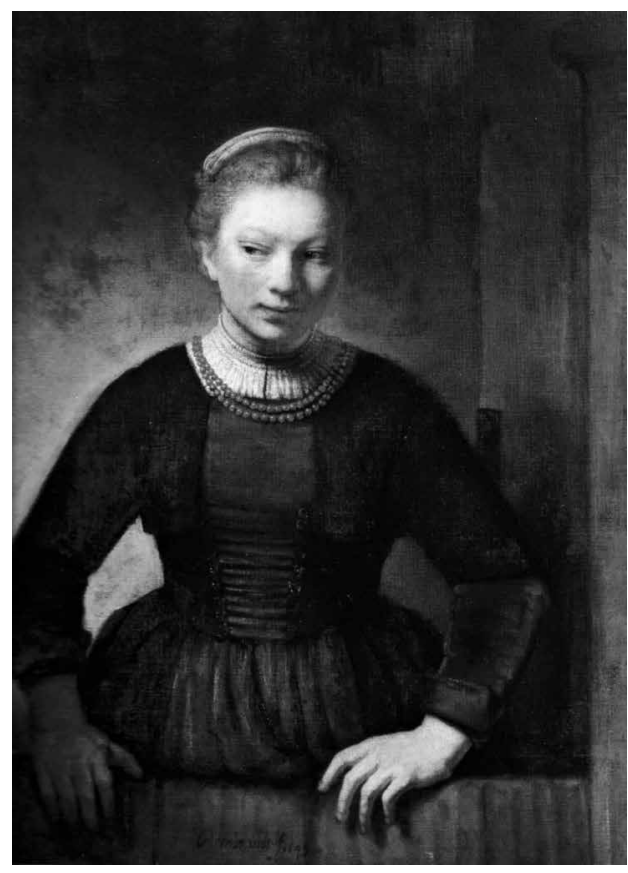

Obrázek 2. Rembrandt Harmenszoon van Rijn, Mladá žena ve dveř́ch, 1645. Art Institute Chicago. Reprodukce z knihy Laura García Sánchez, Rembrandt, Praha 2008, s. 45 